\title{
Research on Relationship between the Social Responsibility and Profitability in Power Enterprise
}

\author{
Jinyu TIAN and Yuan JIANG \\ North China Electric Power University, Department of Economics and Management, NCEPU, Baoding, Hebei, China, 071003 \\ 571368975@qq.com,jy9303@126.com
}

\begin{abstract}
Environmental issues have become a hot topic of social concern, and the social responsibility of enterprise is also increasing people's attention. This paper selected annual report of 43 domestic power industry listed companies from 2012 - 2014 as sample data, and used earning per share (EPS) to measure the profitability of enterprises, to do an empirical research on the relationship between the social responsibility scores and profitability in power enterprise. The study found a positive correlation between social responsibility scores and earning per share. That is to say, the stronger profitability the corporate has, the higher corporate social responsibility scores are.
\end{abstract}

Index Terms - social responsibility, profitability, power enterprise.

\section{Introduction}

There is a new phenomenon that electric power listed companies voluntarily disclose the information of its social responsibility by publishing a separate Social Responsibility Report (CSR) in its annual report. What's the relationship between the profitability and social responsibility in power enterprise? This article did an empirical research on the issue [1].

In the 1980's, social responsibility movement started in developed countries in Europe. Companies began to realize that profit maximization is not the sole purpose of survival, and they should also pay attention to the benefit of other stakeholders, including labor ${ }^{[2]}$. Research on corporate social responsibility began at the same time in China, and many scholars and experts have begun to focus on it and promote its development in recent years. Social responsibility was clearly defined for the business in the new Company Law implemented from January 1, 2006. Company Law points out that the company must abide by the laws and administrative regulations, observe social ethics and business ethics, and accept the supervision of the government and the public, to undertake social responsibility. In addition to the Company Law, many other laws make the regulation of social responsibility from a different range. Law on Protection of the Rights and Interests of Consumers, Contract Law, Guarantee Law and Labor Law respectively embody the protection of consumers, creditor and workers ${ }^{[3]}$.

CSR, which requires companies to break the narrow goal of maximizing profits to realize win-win situation of economic, social and ecological benefits, is an extension of the sustainable development theory and an important reflection of practicing recycling economy and low-carbon economy ${ }^{[4]}$. According to the stakeholder theory, corporate social responsibility can be summarized in one sentence: enterprise is responsible to the shareholders and creates profits while shouldering responsibilities to the development of the state and society, consumers, creditors, community, etc ${ }^{[5]}$.

Based on the corporate social responsibility, this article deeply analysed the relationship between the social responsibility and earning per share (EPS) that formed by combination of social responsibility practice and normalization operation in the power enterprise, and did an empirical test on the electric power enterprise, in order to improve the social responsibility information disclosure in power enterprise and promote the healthy development of the electricity market.

\section{Research Design}

A. Selection of samples and source of data

This paper selects the Shanghai Stock Exchange and Shenzhen Stock Exchange listed power companies as samples, excluding the ST companies and the companies listed after January 1, 2012, and obtains a total of 43 sample companies. Based on the 2012-2014 publicly disclosed annual report of these listed companies, this paper collected related data in accordance with the established indicators. Annual financial reports come from websites: http://finance.sina.com.cn/, http://www.hexun.com/ and http://www.eastmoney.com/, and the stock prices come from GF Securities.

\section{B. Variable definition}

RKS, committed to provide objective and scientific corporate responsibility rating information for social responsibility investor (SRI), social responsibility consumers and the social public, is China's global corporate social responsibility authoritative third-party agencies ${ }^{[6]}$. RKS carries out professional work in three areas: rating in the listed company social responsibility report, rating of China's listed companies ESG sustainable development and social responsibility investors' service. RKS developed the first domestic listed company social responsibility report rating system independently, and held the A-share listed company social responsibility report peak BBS at the end of each year, which has become authoritative communication platform of listed company social responsibility ${ }^{[7]}$.

The professional evaluation system of listed company social responsibility report investigates a corporate from five aspects: the shareholders' liability, the employees' liability, the responsibility of suppliers and consumers' rights and interests, environmental responsibility and social responsibility. Each 
aspect set up the secondary and tertiary index to evaluate comprehensive social responsibility respectively, and there are 13 secondary indicators, 37 tertiary indicators ${ }^{[8]}$.

Profitability is the common concern of stakeholders, is the foundation of enterprise's survival and development. This paper chooses the comprehensive index earnings per share as a measure of profitability. Earnings per share refer to the ratio of net income and total number of ordinary shares this year, which reflects the after-tax profits every share creates ${ }^{[9]}$. The higher the ratio is, the more profits are.

Considering that the corporate social responsibility rating is influenced by various factors, this article selects the company scale, net asset per share and the average price of the stock as control variable. The company scale uses the final amount of total assets to measure. Variable selection and calculation are shown in table 1 .

TABLE I Variable selection and calculation

\begin{tabular}{|l|l|l|l|}
\hline $\begin{array}{l}\text { Variable } \\
\text { categories }\end{array}$ & Variable name & Variable symbol & $\begin{array}{l}\text { Illustration of } \\
\text { evaluation }\end{array}$ \\
\hline $\begin{array}{l}\text { Independe } \\
\text { nt variable }\end{array}$ & $\begin{array}{l}\text { Earnings per } \\
\text { share }\end{array}$ & EPS & $\begin{array}{l}\text { Divide the final net } \\
\text { profit by the total } \\
\text { number of shares }\end{array}$ \\
\hline $\begin{array}{l}\text { Dependen } \\
\text { t variable }\end{array}$ & $\begin{array}{l}\text { Enterprise social } \\
\text { responsibility }\end{array}$ & CSRP & $\begin{array}{l}\text { RSK scores of } \\
\text { corporate social } \\
\text { responsibility }\end{array}$ \\
\hline $\begin{array}{l}\text { Control } \\
\text { variable }\end{array}$ & $\begin{array}{l}\text { Net asset value } \\
\text { per share }\end{array}$ & BE & $\begin{array}{l}\text { The } \\
\text { logarithm of the } \\
\text { final total assets }\end{array}$ \\
\cline { 2 - 4 } & Stock price & PIZE & $\begin{array}{l}\text { Divide the final net } \\
\text { worth by the total } \\
\text { number of shares }\end{array}$ \\
\hline
\end{tabular}

\section{Research hypothesis}

In the process of pursuing economic efficiency, enterprises can also bring social benefit and enhance the social image. Listed companies to fulfill social responsibility relate to its profitability. The stronger the corporate profitability is, the more economic strength that enterprise has to fulfill social responsibility, the more contribution it can make for the government and social public welfare. Enterprise can provide more benefits for the worker and have economic strength to carry out the greening, drainage consolidation, and other environmental protection activities. Based on the above analysis, this paper hypothesized that the electric power enterprise earnings per share and social responsibility are related.

\section{Build a model}

This paper adopts linear model (1) that selects corporate social responsibility scores as explained variable, the company size, the stock price and net assets per share as explanatory variable and model (2) that that selects corporate social responsibility scores as explained variable, the company size, the stock price, net assets per share and earnings per share as explanatory variable, to study the relationship between social responsibility and corporate profitability in electric power enterprise.

$$
\begin{gathered}
C S R P=\alpha_{0}+\alpha_{1} \operatorname{SIZE}+\alpha_{2} B E+\alpha_{3} P+\varepsilon \\
C S R P=\beta_{0}+\beta_{1} S I Z E+\beta_{2} B E+\beta_{3} P+\beta_{4} E P S+\varepsilon
\end{gathered}
$$

\section{Correlation analysis and regression analysis}

\section{A. Descriptive analysis}

There are differences in the social responsibility fulfillment situations. This paper collects 2012-2014 social responsibility scores of 43 power listed companies. The average score of 2012 was 32.44, 2013 was 38.08 and 2014 was 23.24. Twenty-three sample firms is average every year, which account for about half of the total number of samples. This suggests that the sample is reasonable and reliable. The descriptive statistics and the results of correlation coefficient between the variables acquired by the sample are shown in table 2 .

TABLE II Descriptive statistics for the variables and the correlation coefficient between the variables

\begin{tabular}{|c|c|c|c|c|c|c|c|}
\hline Variable & $\begin{array}{c}\text { Mean } \\
\text { value }\end{array}$ & $\begin{array}{c}\text { Standard } \\
\text { deviation }\end{array}$ & CSRP & EPS & P & BE & SIZE \\
\hline CSRP & 37.076 & 20.755 & 1 & & & & \\
\hline EPS & .4065 & .341 & .343 & 1 & & & \\
\hline P & 7.418 & 3.679 & .118 & .661 & 1 & & \\
\hline BE & 3.976 & 2.209 & .128 & .660 & .532 & 1 & \\
\hline SIZE & 14.2 & 1.459 & .211 & .450 & .26 & .27 & 1 \\
\hline
\end{tabular}

The above data is significant at the 0.05 level.

\section{B. The empirical results}

The results of the multivariate linear model are presented in table 3 that selects social responsibility scores as the dependent variable. Model 1 is a foundation, including the size of the company, stock price and net assets per share. Model 2 is on the basis of model 1, introducing the earnings per share as a new control variable, to analyze the relationship between corporate social responsibility fulfillment situation and profitability.

From model 1 and model 2 in table 3, we can see that within the confidence interval at 0.05 , the stock price, net asset per share, and company size has a positive influence on corporate social responsibility, and after the introduction of earnings per share variables, there is no change in the social responsibility score. This suggests the rationality of the analysis model. Model 2 in table 3 shows that within the confidence interval at 0.05 , the coefficient sign between earnings per share and corporate social responsibility evaluation is consistent with the expectation, which suggest that earnings per share has positive influence on corporate social responsibility scores. Assume obtains empirical support. 
TABLE III The regression results of social responsibility scores and earnings per share in power enterprise

\begin{tabular}{|c|c|c|}
\hline Variable & Coefficient in model 1 & Coefficient in model 2 \\
\hline constant term & -6.528 & -6.554 \\
\hline EPS & & 0.123 \\
\hline P & 0.209 & 0.214 \\
\hline BE & 0.805 & 0.808 \\
\hline SIZE & 1.017 & 1.023 \\
\hline
\end{tabular}

The above data is significant at the 0.05 level.

\section{Conclusion and Prospect}

Using earnings per share as a measure of company profitability, scoring for corporate social responsibility and profitability is a significant positive correlation within the confidence interval at 0.05 , so the hypothesis is substantiated. The stronger the corporate profitability is, the more the distribution of dividends or profits to the investors, which makes the investors gain more economic returns to increase investment information. The stronger the corporate profitability is, on the premise of positive legal tax, the more tax payable to the government. Wage and welfare paid to the workers are also linked to enterprise's profit ability and performance level. The stronger the corporate profitability is, the more willing to pay the donation expenditure and sponsorship.

The sample in this paper is limited and just using earnings per share to reflect the profitability of enterprises has certain limitation. A further research can choose different indexes including total assets return rate, to study the effect of profitability of enterprise on social responsibility scores. Moreover, the sample can be extended to enterprises of different ownership or different energy industry, in order to obtain more general research conclusion.

\section{References}

[1] Liu Jinfei. The empirical study on internal governance, profitability and growth ability and corporate social responsibility - Based on the data of listed companies in power industry in China. Shanghai Management Science, 2013(04):69-75.

[2] Li Shu, Xiao Qiuping. Corporate social responsibility, investor behavior and stock liquidity. Research on Financial and Economic Issues, 2012(03):24-31.

[3] Du Jian, Liu Lingli, Zeng Shan. The research of corporate social responsibility and profitability-Based on the contrastive analysis of the textile industry and chemical industry. Friends of Accounting, 2012(13):77-81.

[4] Dong Xueyan. The analysis of corporate social responsibility contribution. Communication of Finance and Accounting, 2012(20):3435.

[5] Yin Kaiguo, Liu Xiaoqin, Chen Huadong. The study on the relationship between the nature of corporate social responsibility and financial performance-The empirical evidence from Chinese listed companies. China soft Science magazine, 2014(06):98-108.

[6] Hu Jianjun, Dong Dayong, Jin Weidong. The study on the relationship between the corporate social responsibility information disclosure and stock price-Empirical evidence of the Shanghai private enterprises. Journal of Business Economics, 2013(04):73-80.

[7] Zhu Yiling, Qi Wenjuan. The research on the relationship between the listed company social responsibility and profitability. Statistics and Decisions, 2011(10):160-162.

[8] Hu Quying. The research of environmental performance and financial performance of listed companies. China Population, Resources and Environment, 2012(06):23-32.

[9] Niu Xiaoqin, Zhang Xiaohui. Correlation research on large corporate social responsibility and financial performance. Friends of Accounting, 2012(06):16-18. 